\title{
Occupational Safety and Health Practices In Agricultural and Livestock Research Organisations, Western Kenya Region
}

\author{
Charles Wafula Buyela ${ }^{1 *}$, Charles Mburu², Paul Njogu ${ }^{3}$ \\ Institute of Energy \& Environmental Technology, JKUAT University, KENYA
}

\begin{abstract}
The Kenya agricultural and livestock research organisation (KALRO) western region is divided into KALROKakamega (non-ruminant) and KALRO-Kitale (food crops) mandated to innovate, improve technological activities that touch on the environment and the livelihood of people. Such practices should comply with occupational safety and health Act (OSHA, 2007) standards. The aim of the study was to assess safety awareness at KALRO-Western Kenya region during the months of April to June 2016. Structured questionnaires, checklist, photographs and observation tools were used for data collection and analyzed using statistical package (SPSS). Study shows that75\% of the respondents in KALRO-Kakamega and $79 \%$ of the respondents in KALRO-Kitale $\left(\chi^{2}=.187, d f=1, p=.665\right)$ agreed that both institutes had safety and health policy. Respondents in KALRO-Kakamega (55\%) and respondents in KALRO-Kitale (63\%) $\left(\chi^{2}=.813, d f=1, p=.367\right)$ had access to such policies necessitating requirement for sensitization to access policy document. Respondents in KALRO-Kakamega(55\%) and respondents in KALRO-Kitale (52\%) $\left(\chi^{2}=9.482, d f=4, p=.050\right)$ indicated that only qualified service engineers maintained machines and equipment. The respondents in both KARLO institutions read labels before using the chemicals KARLO Kakamega $88.7 \%$ and KARLO-Kitale $84.2 \%\left(\chi^{2}=.511, d f=1, p=.475\right)$.Compliance to Safe work procedure as per institution (KALRO-Kakamega $70 \%$, KALRO-Kitale 63\%) $\left(\chi^{2}=.570, d f=1, p=.450\right)$. From the research findings, there were no significant differences in predictor factors for safety awareness at both KALRO-Kakamega and KALRO-Kitale. Training of workers to identify, classify and quantify hazards should be enhanced at the two institutes in order to raise their safety awareness levels as per (OSHA, 2007) standards.
\end{abstract}

Keywords - food crops research, health, KALRO, Non-ruminant research, safety.

\section{INTRODUCTION}

The KALRO Western Kenya Research Institutes were created under the Kenya Agricultural and Livestock Research Act of 2013.The Institutes' main focus is to develop improved technologies that support the upgrading and commercialization of both the non-ruminant livestock and food crops value chains. . KALRO-Western research Institutes conducts focused research on non-ruminants (pigs, poultry, and rabbits) and food crops (cereals, grain legumes, and root and tuber crops) with a potential for commercial farming (KALRO, 2017).

The agricultural production carried out in KALRO-Western Kenya involves crops and live stocks activities. The interaction relationship between people, machines, work environment activities bring about occupational safety and health issues (Kohn, P.J. :Friends, A. M. :Winterberger, 1996). There is no known study carried out to establish the extent of implementation of OSHA standards at the two research institutions since incorporation of KALRO- Mandate - Nationally.

An occupational safety and health plan, anticipates and prevents health problems or hazards that are caused by the work which people do or innovate (Rukunga, 2001). Promotion of safety and health to workers is part of the battle against major scourges of poverty, ignorance and diseases that is still handicap to many developing countries such as Kenya (Glanville, Schilling, \& Wood, 1979). The owners or occupiers of Agricultural Production institute in Kenya are required by the Occupational Safety and Health Act (OSHA, 2007) to carry out initial risk assessments in order to manage their risks at the source. Systematic application of management policies, procedures and practices to tasks help identifying, analyzing, evaluating, treating and monitoring Risk (Hughes \& Ferrett, 2008). Process whereby decisions are made to accept known or assessed risk and/or the implementation of actions to reduce the consequences of probability of occurrence is referred as risk management (Jeremy, 2006). Risk management covers a wide range of hazards and these can be conveniently categorized under the general headings of environment, technical/economic and social/people hazards. Thus risk management is a system of managing risks at work (GOK, 2004). KALRO-Western, like any other production system in Kenya, is expected to create a safe work environment and ensure workers are not affected by workplace hazards in their operations, for efficient and effective unit achievement of their mandate. The purpose of this study was to determine safety awareness among workers and managers in KALRO - Western Kenya region. 


\section{MATERIAL AND METHOD}

\subsection{Study area}

The study was carried out at KALRO - Western Kenya which comprises of Non-ruminant research Institute (Kakamega) and Food crop research Institute (Kitale) during the months of April to June of 2016.

Purposive sampling technique was used for selection of the two KALRO institutions. Both research institutes areas cover approximately 100ha of land for research, pastures and commercial farming. The target populations were managers, supervisors and workers at all levels of production. The organisations had 500 workers hired on casual and contract basis during planting and harvesting activities. The technical team of 142 officers (scientists, laboratory technicians, research officers, and research assistants) as indicated in records of each institutional administration.

\subsection{Study design}

Descriptive cross sectional design was applied in the study which involved structured questionnaires, checklist, photographs and observation tools to collect the required data. The questionnaires were delivered to the respondents. Checklists and observation tool were used to assess the location, process, environment, structure and related factors (hazards) at the workplace.

\subsection{Analysis of data}

Data were analysed using Statistical Package for Social Scientists (SPSS)-version 21.0. The program was used to analyze questionnaires from respondents, edited to completeness, relevance and accuracy. The data was then coded to enable the responses to be grouped into categories for both closed and open ended questions. The statistical data analysis was done using descriptive statistics and displayed using bar charts, tables, frequencies. Inferential analysis conducted for goodness of fit and contingency analysis. Goodness of fit was used for testing what is recommended, expected and what was observed.

\section{Results}

\subsection{Safety and health policy}

Majority of the Workers were aware that safety and health policy was present at their institutions as illustrated in figure 1 (Kakamega $75 \%$, Kitale $79 \%,\left(\chi^{2}=.187, \mathrm{df}=1, \mathrm{p}=.665\right.$ )

\section{Awareness of safety and health policy in the institute}

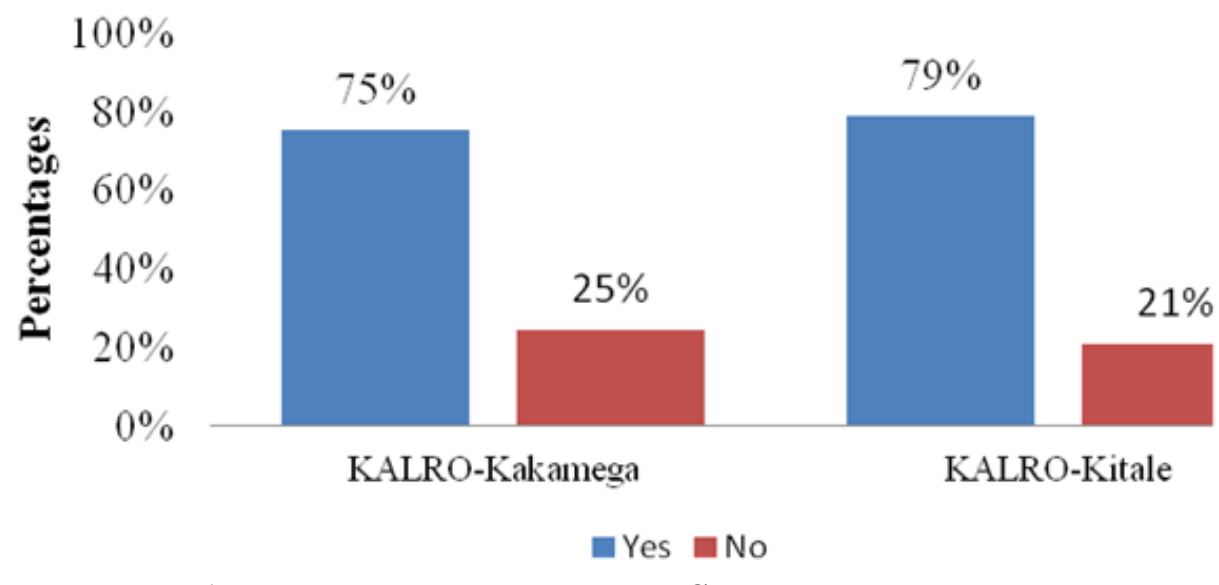

\section{Figure 1: Employee awareness of SAFETy ANd Health Policy}

Awareness of safety and health policy will enhance the performance of an organization through personal development of workforce in avoiding accidents to reduce Insurance financial premium losses (Hughes \& Ferrett, 2008).

\subsection{Workers access to safety and health policy}

Majority of workers in KALRO-Western Kenya; Kakamega 55\%, Kitale 63\%, have access to a copy of the safety and health policy, while $45 \%$ of workers in Kakamega research institute and $37 \%$ in Kitale research institute have no access $\left(\chi^{2}=.813\right.$, $\mathrm{df}=1, \mathrm{p}=.367$ ) as illustrated in Figure 2. 


\section{Access to safety and health policy}

$80 \%$
$60 \%$
$40 \%$
$20 \%$
$0 \%$

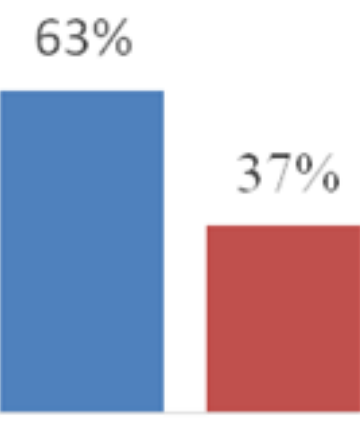

KALRO-Kakamega

KALRO-Kitale

\section{- Yes $n$ No \\ Figure 2: ACCeSsibility to SAFety AND Health Policy}

\subsection{Awareness of policy provisions on health and safety}

The employee awareness on safety and health policy provided per age are presented in the table 1 .

TABLE 1

EMPloyee AWARENESS ON SAFETy AND HeALTh POLICY PROVISIONS AS PER AGE

\begin{tabular}{|c|c|c|c|c|c|}
\hline & & \multicolumn{2}{|c|}{$\begin{array}{l}\text { Respondents awareness of safety and } \\
\text { health policy in the institute }\end{array}$} & \multirow{2}{*}{ Total } & \multirow{2}{*}{$\begin{array}{c}\begin{array}{c}\text { Chi-Square } \\
\text { Tests }\end{array} \\
\text { value 13.674 }\end{array}$} \\
\hline & & Yes & No & & \\
\hline \multirow{4}{*}{ Age of respondents } & 18-28 Years & $38 \%$ & $62 \%$ & $100 \%$ & \multirow{5}{*}{$\begin{array}{c}\mathrm{df}=3 \\
\text { Asymp. Sig. (2 } \\
\text { sided) } .003\end{array}$} \\
\hline & 29-39 Years & $83 \%$ & $17 \%$ & $100 \%$ & \\
\hline & 40-49 Years & $94 \%$ & $6 \%$ & $100 \%$ & \\
\hline & Above 50 years & $81 \%$ & $19 \%$ & $100 \%$ & \\
\hline \multicolumn{2}{|c|}{ Total } & $76 \%$ & $24 \%$ & $100 \%$ & \\
\hline
\end{tabular}

Although there is a large number of workers saying they have access to a safety and health policy, the low significance $\left(\chi^{2}=13.674, \mathrm{df}=3, \mathrm{p}=.003\right)$ which is less than .05 suggest that there is a big difference between those who access and those who do not access as per age. The chi square value asymptotic significance indicates the awareness of safety and health policy is significant in raising safety awareness.

\subsection{Pesticides procurement, storage and disposal}

KALRO-Western-Kenya procures their Chemicals (pesticide) through the procurement department as requested by the user sections. Research findings revealed that pesticide storage in farm store faces a myriad of challenges including excessive purchase of chemicals/pesticides and storage of excessive unused chemicals/ pesticides which is not a good practice as per occupational safety and health regulation. Chemicals/Pesticides are supposed to be stored in a well ventilated and proper system of lighting for easy retrieval of the same to minimize aerosol exposures to them which is a good practice as per occupational safety and health regulation Act (2007). From the interviews, excess chemicals/pesticides not used is often sprayed on barren land and containers perforated before disposal. Safe disposal of pesticides should involve decontamination of unutilized toxicants, proper disposal methods and Label reading before using chemical to be sought. 


\subsection{Awareness of safe work procedures}

Among the total number of employees in KALRO-Western Kenya, Kakamega $70 \%$, Kitale $63 \%\left(\chi^{2}=.570, \mathrm{df}=1, \mathrm{p}=.450\right)$ were aware of safe work procedure in their respective research institute for routine operations in the workplace activities.

\section{Familiarity of safe work procedure for handling chemicals/pesticides}

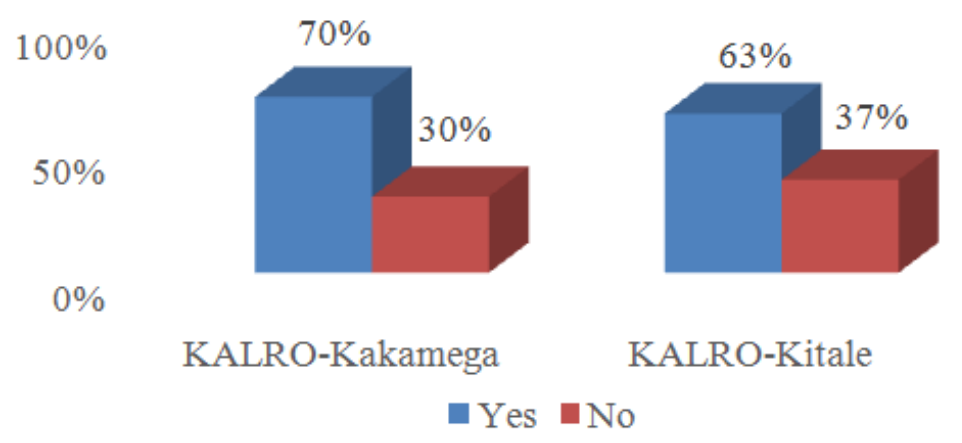

\section{FIGURE 3: EMPLOYEES AWARENESS OF SAFE WORK PROCEDURES}

Workers who do not follow safe work procedure observed in the population did not go through either secondary, college or university education were prone to accidents; Kakamega 30\%, Kitale 37\%. During safe work procedures development, hazards that are likely to cause injuries are identified, assessed, evaluated and controlled, having positive impact towards raising level of safety awareness at workplace. The high percentage of safety and health awareness in research institutions is due to high pronouncement of safe work procedures in their daily activities.

TABLE 2

AGE OF RESPONDENTS AND COMPLYING TO WRITTEN WORK PROCEDURES

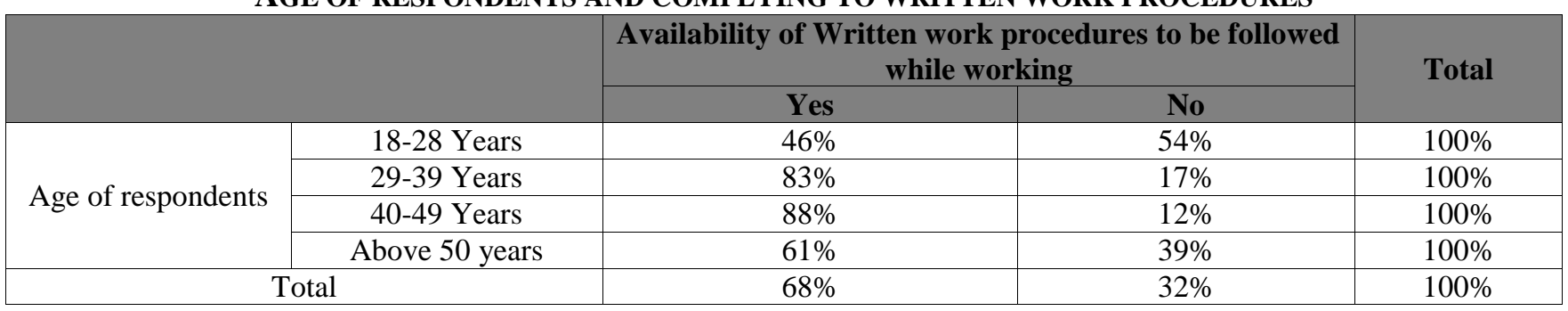

KALRO-Western Kenya employees (18-28 years) 54\% do not follow written work procedure at their workplace hence are required to be sensitized to follow written work procedures in order to avoid accidents at the workplace.

\subsection{Label reading before using pesticides/Chemicals}

The respondents in both KARLO institutions read lebels before using the chemicals (KARLO-Kakamega $88.7 \%$ and KARLO-Kitale $84.2 \%,\left(\chi^{2}=.511, \mathrm{df}=1, \mathrm{p}=.475\right.$, table 3$)$.

TABLE 3

EMPLOYEES READING LABELS ON CHEMICALS /PESTICIDES BEFORE USE

\begin{tabular}{|c|c|c|c|c|}
\hline & \multicolumn{2}{|c|}{$\begin{array}{c}\text { Reading labels on chemicals/pesticides before use } \\
\text { by respondents }\end{array}$} & \multirow{2}{*}{ Total } & chi square tests \\
\cline { 1 - 4 } & Yes & No & & p value $=.511$ \\
\cline { 1 - 4 } & $88.7 \%$ & $11.3 \%$ & $100.0 \%$ & $\mathrm{df}=1$ \\
\hline KALRO-Kakamega & $84.2 \%$ & $15.8 \%$ & $100.0 \%$ & \multirow{2}{*}{ assymp sig $(2 \mathrm{sided})=.475$} \\
\hline
\end{tabular}




\subsection{Population that is aware of procedures for mixing categories of Pesticides}

From the results table $4,51 \%$ in KARLO-Kakamega and $42 \%$ in KARLO-Kitale $\left(\chi^{2}=.875, \mathrm{df}=1, \mathrm{p}=.350\right)$ indicated that they mix various categories of pesticides before using them. The statistics tests indicate that there is no significant difference between the two centres when it comes to knowledge of mixing pesticides to achieve sound results. Mixing and loading remain a potential source of pesticide exposures (Kariathi et al., 2016). This is supported by Cornell (1992) study that pesticides must only be issued to staff who has appropriate training. The trained operators will be aware of the pesticides being used, able to carry out spraying safely and take precaution in case of a spill.

\section{TABLE 4}

EMPLOYEES DIRECTLY EXPOSED TO CHEMICALS THROUGH MIXING THEM

\begin{tabular}{|c|c|c|c|c|}
\hline \multirow{2}{*}{} & \multicolumn{2}{|c|}{$\begin{array}{c}\text { Mixing of various categories of pesticides } \\
\text { by respondents }\end{array}$} & \multirow{2}{*}{ Total } & Chi square tests \\
\cline { 2 - 4 } & Yes & $49 \%$ & $100 \%$ & value =.875 \\
\hline KALRO-Kakamega & $51 \%$ & $58 \%$ & $100 \%$ & $\mathrm{df}=1$ \\
\hline KALRO-Kitale & $42 \%$ & $51 \%$ & $100 \%$ & Assymp sig $(2 \operatorname{sided})=.350$ \\
\hline Total & $49 \%$ & &
\end{tabular}

\subsection{Knowledge of handling plant and animal waste}

The level of agreement that animal and plant waste are highly handled in a hygienic manner was high in KALRO Kakamega with a percentage of $62 \%$ followed with KALRO Kitale $42 \%\left(\chi^{2}=5.986, \mathrm{df}=4, \mathrm{p}=.200\right)$.

\section{TABLE 5}

EMPLOYEES KNOWLEDGE OF HANDLING PLANT AND ANIMAL WASTE

\begin{tabular}{|c|c|c|c|c|c|c|c|c|}
\hline & & \multicolumn{5}{|c|}{$\begin{array}{l}\text { Animal and plant wastes handled in a highly hygienic manner } \\
\text { in the institute }\end{array}$} & \multirow[t]{2}{*}{ Total } & \multirow{2}{*}{\begin{tabular}{|c|}
$\begin{array}{c}\text { Chi square } \\
\text { tests }\end{array}$ \\
value $\mathbf{5 . 9 8 6}$
\end{tabular}} \\
\hline & & $\begin{array}{l}\text { Strongly } \\
\text { disagree }\end{array}$ & Disagree & Neutral & Agree & $\begin{array}{l}\text { Strongly } \\
\text { agree }\end{array}$ & & \\
\hline \multirow{2}{*}{$\begin{array}{l}\text { Respondents } \\
\text { institute of work }\end{array}$} & $\begin{array}{l}\text { KALRO- } \\
\text { Kakamega }\end{array}$ & $6 \%$ & $19 \%$ & $11 \%$ & $53 \%$ & $9 \%$ & $100 \%$ & $\mathrm{df}=4$ \\
\hline & $\begin{array}{l}\text { KALRO- } \\
\text { Kitale }\end{array}$ & $16 \%$ & $21 \%$ & $21 \%$ & $37 \%$ & $5 \%$ & $100 \%$ & \multirow{2}{*}{$\begin{array}{c}\text { Assymp sig } \\
(2 \text { sided })= \\
.200\end{array}$} \\
\hline \multicolumn{2}{|c|}{ Total } & $10 \%$ & $19 \%$ & $16 \%$ & $47 \%$ & $8 \%$ & $100 \%$ & \\
\hline
\end{tabular}

The overall agreement is at 55\% in KALRO western Kenya in handling wastes and protection of workers from biological agents while working. The protection may be rated as moderate/fair in KALRO western Kenya. There was no significance difference between the two centres when it comes to knowledge in handling plant and animal wastes.

\subsection{Chemicals/Pesticide poisoning and emergency action plan awareness}

Workers are not aware of emergency action plan in case of chemicals/ pesticide poisoning and any other form of emergency Kakamega 51\%, Kitale 63\%. $\left(\chi^{2}=1.681, \mathrm{df}=1, \mathrm{p}=.195\right)$.

Availability of guidelines /emergency measures in case of chemicals/pesticide poisoning

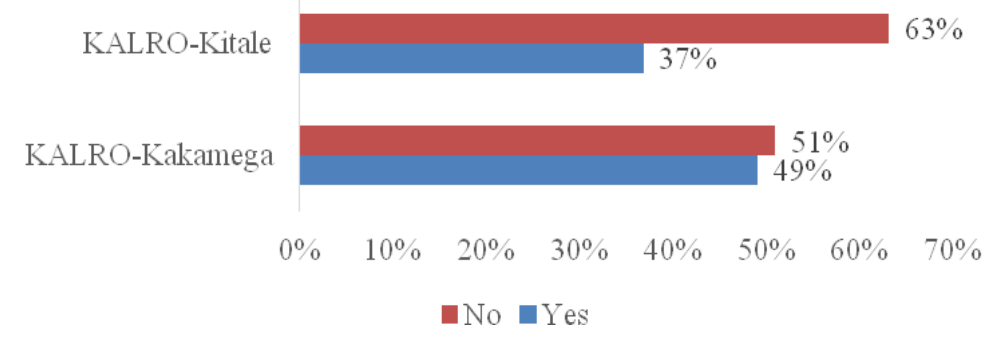

FIGURE 4: AVAILABILITY OF EMERGENCY MEASURE AND GUIDELINES 
There are only Kakamega 49\%, Kitale 37\% workers that are aware of emergency measures in case of emergency or chemical/pesticide poisoning due to their specialized task undertaking at their workplace. There was no significant difference between the two centres when it comes to chemical emergency action plan. In the event of chemical/pesticide poisoning, the first aid procedure arrangement for calling ambulance and rescue team is not well known to the staff in KALRO-Western Kenya. There is a need to put in place a more detailed emergency plan which may take account of findings of initial risk assessment for incidents/accidents at work place. Emergency procedure is about control procedure and equipment to limit the damage to people and property caused by an incident/accident, for instance pesticides should always be applied in the direction of the flow of wind. Application of pesticides should be started near downward edge of the field and should proceed upward with the back to the wind so that the operator is always in an untreated area. If there is substantial drift/windy period, pesticides should not be applied. Mathew G. A. (1985) noted that if pesticides are accidently swallowed, medical advice should be sought without delay.

\subsection{Machinery and equipment safety}

\section{TABLE 6}

KNOWLEDGE ON MAINTENANCE OF EQUIPMENT AND TOOLS

\begin{tabular}{|c|c|c|c|c|c|c|c|}
\hline & \multicolumn{9}{|c|}{$\begin{array}{c}\text { Equipments provided are well maintained by qualified } \\
\text { service engineers }\end{array}$} & \multirow{2}{*}{ Total } & Chi square tests \\
\cline { 5 - 7 } & $\begin{array}{c}\text { Strongly } \\
\text { disagree }\end{array}$ & Disagree & Neutral & Agree & $\begin{array}{c}\text { Strongly } \\
\text { agree }\end{array}$ & & value $=9.482$ \\
\hline $\begin{array}{c}\text { KALRO- } \\
\text { Kakamega }\end{array}$ & $9 \%$ & $17 \%$ & $19 \%$ & $42 \%$ & $13 \%$ & $100 \%$ & Assymp sig (2-sided) $=.050$ \\
\hline $\begin{array}{c}\text { KALRO- } \\
\text { Kitale }\end{array}$ & $26 \%$ & $11 \%$ & $11 \%$ & $47 \%$ & $5 \%$ & $100 \%$ & \\
\hline Total & $14 \%$ & $15 \%$ & $17 \%$ & $43 \%$ & $11 \%$ & $100 \%$ & \\
\hline
\end{tabular}

Workers agree that equipment and tools used on the farm are well maintained 54\%. The level of agreement was high in KALRO-Kakamega 55\%, KALRO-Kitale was $52 \%\left(\chi^{2}=9.482, \mathrm{df}=4, \mathrm{p}=.050\right)$. There is significant difference in terms of maintenance of equipment and tools in the two centres due to administrative priority put to safety of machines equipment at two centres. This was due to the nature of specialized tasks at workplace. Work equipment needs to be properly maintained so that it continues to operate safely and in the way it was designed to perform. The amount of maintenance will be stipulated in manufacturers' instructions and will depend on the amount of use, the working environment and type of equipment. High speed, high-hazard machines, which are heavily used in adverse environment, may require very frequent maintenance, whereas simple hand tools may require very little maintenance.

KALRO-Western Kenya workers and managers are aware as to why equipment maintenance is important in order to control machinery risks and poor ergonomic issues at KALRO-Western which should be enhanced further.

\section{CONCLUSION}

From the research findings, the management and workers in KALRO-Western Kenya region access the safety and health policy which is evidence based for decision making in creating safety awareness. There were no significant differences in predictor factors for safety awareness at both KALRO-Kakamega and KALRO-Kitale. Positive predictors of safety awareness in the two research organizations included compliance to safe work procedures, reading pesticides labels before handling or mixing, good machinery maintenance practices, knowledge of handling plant and animal waste, in line with(OSHA, 2007) standards.

\section{ACKNOWLEDGEMENTS}

The authors are grateful to the Management team of Kenya Agricultural and Livestock Research Organisations in western region for their technical support. Special thanks also to Jomo Kenyatta University of Agriculture and Technology (JKUAT) for providing introductory letter to KALRO.

\section{REFERENCES}

[1] Cornel, J. S. (1992). Safety Precaution in the use of Herbicides. UK: British Rail. 
[2] Food and Agriculture Organization of the United Nations (FAO). (2002). International Code of Conduct on the Distribution and Use of Pesticides.

[3] Glanville, H. De, Schilling, R. S. F., \& Wood, C. H. (1979). occupational health: A manual for health workers in developing countries. African Medical and Research Foundation.

[4] GOK. The Factories and Other Places of Work (Safety and health Committees) Rules, Legal Notice No. 3 I (2004). Nairobi.

[5] Hughes, P., \& Ferrett, E. (2008). Introduction to health and safety in construction: the handbook for construction professionals and students on NEBOSH and other construction courses (3rd ed.). Amsterdam: Butterworth-Henemann.

[6] Jeremy, S. (2006). Health and Safety Pocket Book. Burlington: Butterworth-Heinemann.

[7] KALRO. (2017). Vision and Mission | Kenya Agricultural \&amp; Livestock Research Organization. http://www.kalro.org/vision-andmission

[8] Kariathi, V., Kassim, N., Kimanya, M., \& Yildiz, F. (2016). Pesticide exposure from fresh tomatoes and its relationship with pesticide application practices in Meru district. Cogent Food \& Agriculture, 2(1), 3-12. http://doi.org/10.1080/23311932.2016.1196808

[9] Kohn, P.J. :Friends, A. M. :Winterberger, A. C. (1996). Fundamentals of occupational safety and health. Rockville North Carolina.

[10] Mathews, G.A. (1985). Pesticide application method. (English language Book society Edition), London: Longman

[11] Mc grath, J. M. (2011). The role of equipment warning labels in the industrial workplace. International Journal of Occupational Safety and Ergonomics, 17(1), 49-60. http://doi.org/10.1080/10803548.2011.11076871

[12] OSHA. (2007). The Occupational Safetyand Health Act, 2007 (Vol. 1). Kenya.

[13] Rukunga, K. . (2001). Environmental Health for East Africa. Nairobi, Kenya: African Medical and Research Foundation.

[14] Tonui, W. K. (2007). laboratory safety handbook. Nairobi: King's Script publishers. 